76 巻 763 号 $(2010-3)$

\title{
ループ型熱音響エンジンの諸特性の把握と高効率化に向けた検討* （車両搭載を視野に入れたシステム構築の検討）
}

\author{
勝田正文*1, 納 富信*2, 鈴木啓史*3 \\ 谷 洋 平*3, 平澤 顕*3, 柳 寿 宜*3
}

\section{Study on the Looped-Type Thermoacoustic Prime Mover for the High Efficient and Practical System}

\author{
Masafumi KATSUTA, Makoto NOHTOMI*4, Keishi SUZUKI, \\ Yohei TANI, Ken HIRASAWA and Hisanori YANAGI \\ ${ }^{* 4}$ Graduate School of Environment and Energy Engineering, Waseda University, \\ 1011 Nishi-tomita, Honjo-shi, Saitama, 367-0035 Japan
}

\begin{abstract}
In this research, our interests focused on the thermoacoustic prime mover to recover the waste heat and effective utilization of it. The advantages of this prime mover are the flexibility for various heat sources as an external engine and a possibility as the cost effective system due to simple structure. To improve the total thermal efficiency, various efforts have been made experimentally to grasp the optimization of stack structure which plays an important role to energy conversion. Finally, discussions on the future application of prime mover aiming to utilize the waste energy of exhaust gas are made and, by installing a membrane of natural rubber inside the tube, the acoustic intensity has increased by $20 \%$.
\end{abstract}

Key Words : Thermoacoustic Prime Mover, Stack Structure, Recovery of Waste Heat

\section{1. 緒言}

近年，地球環境問題が顕在化する中，排エネルギー の有効活用が各分野で求められている，そこで，排熱 を回収して有効利用するシステムとして，(1)外燃機関 であるため熱源の自由度が高い(1)(2)，(2)単純な構造のた め安価で製造できる，という長所を持つ熱音響エンジ ンに注目した。熱音響現象は音響エネルギ一と熱エネ ルギーとの相互変換により発生する現象で，音波が自 由空間を伝播する時，流体は断熱的に変化するので周 囲との熱のやり取りは生じないが，狭い空間内を伝播 する時は，音波は近傍固体との間で熱交換が行われる.

本研究では進行波型熱音響エンジンの高効率化の ために，心臓部であるスタック部構造の最適化の指針 を得ること，また高効率化の阻害となっている質量流 を遮断する方法，その影響を把握する，そこから害機 搭載に向けて ${ }^{(3)}$, 発電システムへの展開や, 排熱の回 収方法・車両搭載スペース等老考慮した装置形状の決 定に資する指針を得ることを目的とする.

* 原稿受付 2009 年 9 月 18 日:

*1 正員, フェロー, 早稲田大学大学院環境・エネルギー研究科 (西 367-0035 本庄市西富田 1011)

*2 正員, 早稲田大学大学院環境・エネルキ゚ー研究科。

*3 早稻田大学理工学術院.

E-mail : nohtomi@waseda.jp

\section{2. 実験装置およひ央験方法}

2-1 装置全体图実験装置の全体図, スタック詳 細図を図 1 に示す。

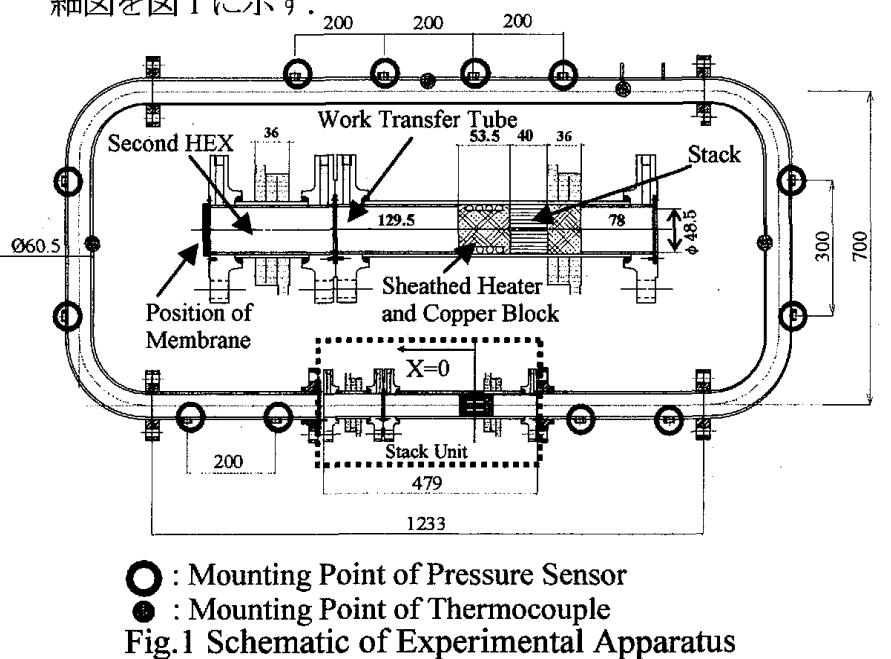

装置は、ループ周長 $4.2 \mathrm{~m}$, 外径 $60.5 \mathrm{~mm}$, 内径 $52.7 \mathrm{~mm}$ のステンレスパイプで構成され，長辺部が $1233 \mathrm{~mm}$, 短辺部が $700 \mathrm{~mm}$ の長さ, 作動ガスを $\mathrm{Ar}$ とし, $75 \mathrm{~Hz}$ の波が励起される．また，音響波を解析寸るためにル 一プに沿ってひずみゲージ式圧力センサを 12 個設置 し,2-Sensor-Methodにより音響強度を把握する. スタッ クは金属製の平織りメッシュを積層して構成し，加熱 
部（高温端）はシースヒータを巻きつけた。

銅ブロックを管内に挿入してスタック端面を加熱, 低温部（低温端）は管外から循環水により冷却する.

電気ヒータによる加熱と，循環水による冷却からス タック雨端に急激な温度勾配が生じることで管内の作 動ガスが自励振動を始める：そこで各部圧力ならびに 温度を測定し，音響波の挙動を観察する.

\section{3. 実験結果及び考察}

\section{3・1 質量流の蒀断高温端からスタックと逆方} 向（WTT:Work Transfer Tube）八流れ出寸質量流を遮 断するために，厚さ $0.082 \mathrm{~mm}$ のゴム膜を設置した。位 置は図 1 内部の左端であり，実験条件は $500 \mathrm{~W}$ 入力, Ar600kPa 封入とした. 図 2 に高温端・WTT での膜の 有無による温度履歷の比較を，表 1 に入熱開始から 4000 秒後の圧力振幅, 音響強度を示す.

ゴム膜未設置時に見られる発振後の高温端温度の 急激な降下と WTT 部の温度上昇が，ゴム膜の挿入に より抑制されたことからゴム膜は熱の流出を遮断し， 振幅で $9 \%$, 音響強度で $22 \%$ 向上する効果を確認した。

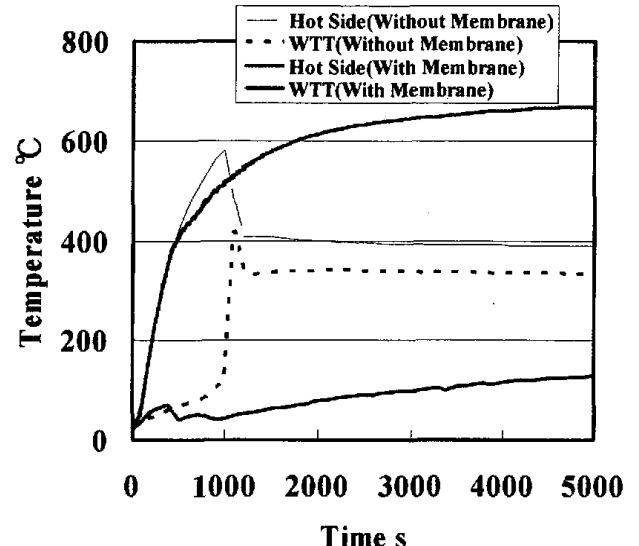

Fig.2 Temperature History(With \& Without Membrane) Tablel Experimental Results (With \& Without Membrane)

\begin{tabular}{c|c|c}
\hline \hline Membrane & $\begin{array}{c}\text { Pressure Amplitude } \\
\mathrm{kPa}\end{array}$ & $\begin{array}{c}\text { Sound Intensity } \\
\mathrm{kW} / \mathrm{m}^{2}\end{array}$ \\
\hline Without & 22.8 & 16.2 \\
\hline With & 24.9 & 19.8 \\
\hline
\end{tabular}

$3 \cdot 2$ 加熱昷の影需 ゴム膜を挿入した状態（膜 位置は高温端から $337 \mathrm{~mm}$ ) で $300 \mathrm{~W}$ から $700 \mathrm{~W}$ まで加 熱量を変化させた実験を行った．各加熱量での高温端 の温度履歷を図 3 に加熱量に対する音響強度を図 4 に 示す. 加熱量の増加とともに高温端温度は上昇し, $300 \mathrm{~W}$ 入力で約 $400^{\circ} \mathrm{C}, 700 \mathrm{~W}$ 入力で約 $800^{\circ} \mathrm{C}$ で発振し た。アイドリング時から高負荷運転時の排ガス温度レ ベルまで安定した発振が可能であり，音響強度，圧力 振幅は加熱量と比例関係にある。

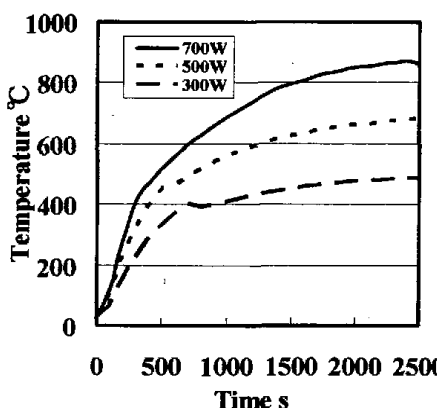

Fig. 3 Temperature History at Hot Side

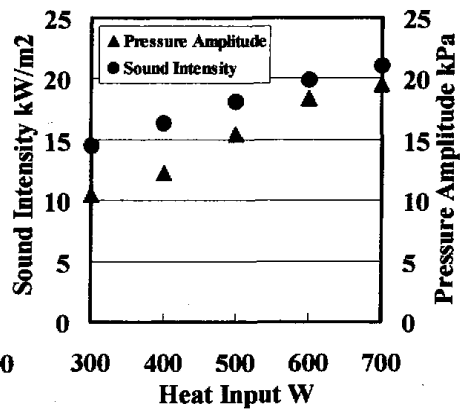

Fig. 4 Sound Intensity \& Pressure Amplitude vs. Heat Input

\section{4. 展望}

$4 \cdot 1$ 搭载車両・設置方法に関して 実車に搭載 した状態を模擬した高温・低温端温度制御による実験 が必要である. 加えて車載方法としては，触媒後の排 管と直交する形で隔壁式熱交換器を設置し(図 5), セン ターマフラーを囲う形で車体下に搭載することを想定 している. (図 6) 触媒からリアマフラーまでの長さ, サイドメンバ一間の幅を考慮すると, 全長で $3 \sim 4 \mathrm{~m}$ 程 度のループ管の構成となる。

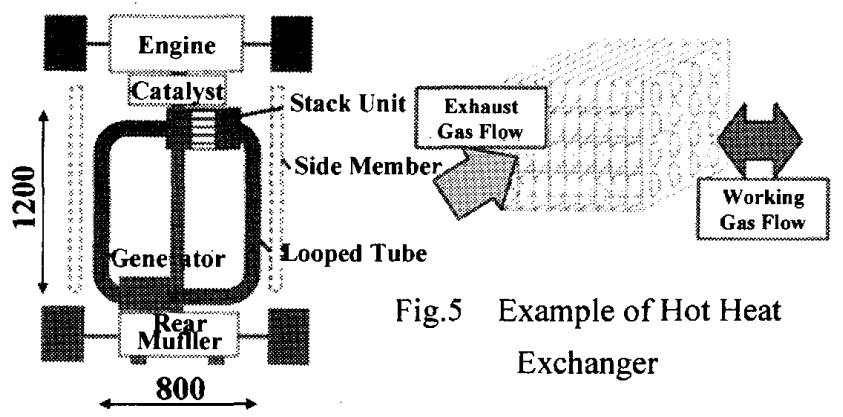

Fig.6 Image View of Thermoacoustic System on Vehicle

\section{5. 結 言}

（1）ゴム膜を扱入することにより質量流は遮断され， 音響強度が 1.2 倍に堌幅した。

(2) 広い温度範囲で安定的に運転・発振が可能である ことが分かった。

\section{参考 文 翰}

(1) Matsubara, Thermoacoustic cooling system that aimed at small-scale self sufficiency, IEICE technical report. Ultrasonics 106(482) (2007) pp.19-24

(2) Komiya, Trial on the thermoacoustic cooling by using the solar heat energy as input energy Study on loop tube cooling system for practical application $\sim$,The Acoustical Society of Japan (2008) pp.1289

(3) Hatazawa, Performance of a Thermoacoustic Sound Wave Generator driven with Waste Heat of Automobile Gasoline Engine, Transactions of the Japan Society of Mechanical Engineers. $B$ 70(689) (2007) pp.292-299 